Arab Univ. J. Agric. Sci., Ain Shams Univ., Cairo, 13(3), 901-913, 2005

\title{
PRODUCTIVITY OF DILL ( ANETHUM GRAVEOLENS L.) AS INFLUENCED BY DIFFERENT ORGANIC MANURE RATES AND SOURCES
}

[60]

\author{
Khalid, Kh.A. ${ }^{1}$ and A.M. Shafei ${ }^{2}$
}

\begin{abstract}
Dill (Anethum graveolens L.) plants were cultivated during two successive seasons (2002/2003 and 2003/2004). The experimental were conducting at the Experimental Farm, National Research Center (NRC), Egypt, to study the effect of different combination of organic fertilizers such as chicken and sheep manure and its rates on dill (Anethum graveolens L.) plants. The obtained results indicated that, treated plants with different combination of organic fertilizers and its rates resulted in a significant increase in growth and yield characters, i.e. plant height, branch number, leaf number, umbel number, fresh weight, dry weight and fruit yield / plant in comparison with control plants. Chemical composition analysis of treated plants showed an increase in the essential oil percentage and main components (Carvone (R) and Limonene) of essential oil extracted from dill (Anethum graveolens L.) fruits. Treated plants showed a decreases in the heavy metals content in the plant tissues comparison to untreated plants. Also these results indicated that the application of organic manure reduced the harmful effects of hazardous heavy metals.
\end{abstract}

Key words: Dill (Anethum graveolens L.), Organic fertilizers, Chicken manure, Sheep manure, Vegetative growth, Essential oil, Heavy metals.

\section{INTRODUCTION}

Dill (Anethum graveolens L.) an annual herb belong to family Apiaceae, native to Europe, is naturalized to North America and West Indies. Principal dill production areas are India, Pakistan, Egypt, Fiji, Mexico, United States, England, Hungary, Germany and
Netherlands. The plant growth erects and can reach a height of one meter. It is characterized by hallow stems, blue green leaves, and yellow flowering compounds umbels, which produce a dried ripe fruits commonly called, seeds.

As a medicinal plant, Dill has been used as an antispasmodic, carminative, diuretic, stimulant and stomachic, also

1- Cultivation and Production of Medicinal and Aromatic Plants Department, National Research Center, Dokki, Cairo, Egypt.

2- Soils \& Water Use Department, National Research Center, Dokki, Cairo, Egypt. 
Arab Univ. J. Agric. Sci., Ain Shams Univ., Cairo, 13(3), 901-913, 2005

some pharmacological effects of dill have been reported, such as antimicrobial (Delaquis et al 2002), antihyperlipidemic and antihypercholesterolaemic (Yazdanporast and Alavi 2001).

As a folk remedy, dill considered for some gastrointestinal ailments such as flatulence, indigestion, stomachache and colic (Duke, 2001). Dill fruits has an antispasmodic effect on the smooth muscles of the gastrointestinal tract (Fleming, 2000), and fruit extracts have significant mucosal protective and antisecretory effects of the gastric mucosa in mice (Hosseinzadeh et al 2003).

Jozef $\boldsymbol{e t}$ al (2002) reported that, there are variations of chemical composition of the essential oil of dill herb depending on its stages of vegetation. Carvone and limonene are the main components of essential oil extracted from Anethum graveolens L. fruits while ó Phellandrene is the main component of essential oil extracted from Anethum grveolenus L. herb (Huopalahti and Linko, 1983). In north Netherlands $(+)$ Carvone is being introduced as a commercial sprouting inhibitor for potato tubers (Oasterhaven et al 1995).

Hornok (1980) indicated that, NPK fertilization not only effective on the quantity of vegetative and generation mass, but on the essential oil content of Anethum graveolens L., also Hussien 1995 reported that, nitrogen fertilization was more effect on the dill essential oil constituents. NPK fertilization and micronutrients increased the vegetative growth and essential oil content of some medicinal Apiaceae plants (Khalid, 1996).

Pollution with chemical fertilizers arose as an aim of health cure, thus attempts were done for solving problems of chemical fertilization, and the organic farming technique represents a move towards an alternative system of agriculture (Abd-Allah et al 2001).

Organic material such as sheep and chicken manure improve soil physical properties (structure and aggregation) and soil chemical properties (decrease soil pH, increase Cation Exchange Capacity and enhance the most nutrient) that important for plant growth (Snyman et al 1998).

Application of organic fertilizer increased the biomass yield of the main crop and total essential oil yields of davana plant (Parakasa Rao et al 1997). Marculescu et al (2002) revealed that, the soil with its content in macro and microelements, enhanced by the use of organic fertilizers, plays an essential role in the plants growing and development, in the biosynthesis of the organic substances at all level, also it can be noted that, the vegetative mass is rich and the amount of essential oil is high in Chrysanthemum balsamita L. plant when using organic fertilizer. Barker and Bryson (2002) reported that, heavy metals pollutant are not degraded during composting but may be converted into organic combinations that have less bio availability than mineral combinations of the metals.

1- Cultivation and Production of Medicinal and Aromatic Plants Department, National Research Center, Dokki, Cairo, Egypt.

2- Soils \& Water Use Department, National Research Center, Dokki, Cairo, Egypt. 


\section{Dill productivity}

The main objective of the present investigation is to study the effect of different levels of some organic fertilizers (chicken and sheep manure) on the growth, yield, essential oil and heavy metals content of dill plants and also study the effect of organic fertilizers on the heavy metals content in soil.

\section{MATERIAL AND METHODS}

This study was conducted during two successive seasons of 2002 / 2003 and 2003 / 2004 at the Experimental Farm, National Research Center (NRC), Egypt.

Seeds of dill (Anethum grveolenus L.) were kindly produced from Medicinal and Aromatic Plants Dept., Ministry of Agriculture, Egypt.

Mechanical and chemical properties of the soil, and chemical analysis of organic manure (sheep and chicken manure) used in this study were determined according to Jackson (1973) and Cottenie et al (1982) and are presented in Tables (1, 2 and 3).

Seeds were sown on October $31^{\text {st }}$ in both seasons. The experimental design was complete randomized blocks with four replicates.

The experimental area (plot) was $4 \mathrm{~m}^{2}$ ( $2 \mathrm{~m} \times 2 \mathrm{~m}$ ) containing 4 rows (Each plot contained 32 plants), distance between hills was $25 \mathrm{~cm}$ and $50 \mathrm{~cm}$ apart. Thinning for two plants / hill was made 45 days after sowing.
All agriculture practices operation other than experimental treatments were don according to the recommendations of Ministry of Agriculture, Egypt.

Each experiment included 7 treatments representing the different combinations of Farm Yard Manure as Sheep Manure and Chicken Manure in addition the control treatment as follows:

1- Control (recommended NPK fertilizer).

2- $30 \mathrm{~m}^{3}$ Sheep Manure / fed. $+0 \mathrm{~m}^{3}$ Chicken Manure / fed.

3- $25 \mathrm{~m}^{3}$ Sheep Manure / fed $+5 \mathrm{~m}^{3}$ Chicken Manure / fed.

4- $20 \mathrm{~m}^{3}$ Sheep Manure $+10 \mathrm{~m}^{3}$ Chicken Manure / fed

5- $15 \mathrm{~m}^{3}$ Sheep Manure / fed. $+15 \mathrm{~m}^{3}$ Chicken Manure / fed.

6- $10 \mathrm{~m}^{3}$ Sheep Manure $+20 \mathrm{~m}^{3}$ Chicken Manure / fed.

7- $5 \mathrm{~m}^{3}$ Sheep Manure / fed. $+25 \mathrm{~m}^{3}$ Chicken Manure / fed.

8- $0 \mathrm{~m}^{3}$ Sheep Manure $+30 \mathrm{~m}^{3}$ Chicken Manure / fed.

Table 1. Mechanical properties of the soil.

\begin{tabular}{|cccc|}
\hline Texture & $\begin{array}{c}\text { Sand } \\
(\%)\end{array}$ & $\begin{array}{c}\text { Silt } \\
(\%)\end{array}$ & $\begin{array}{c}\text { Clay } \\
(\%)\end{array}$ \\
\hline Clay & 24 & 9 & 67 \\
\hline
\end{tabular}

Table 2. Chemical properties of the soil.

$\begin{array}{|cccccc|}\begin{array}{c}\text { Available } \\ (\mathrm{mg} / 100 \mathrm{~g})\end{array} & \begin{array}{c}\text { Total } \\ (\mathrm{mg} / \mathrm{l00 \textrm {g }})\end{array} & \begin{array}{c}\text { Soluble anions } \\ (\mathrm{meq} / \mathrm{L})\end{array} & \begin{array}{c}\text { Soluble cations } \\ (\mathrm{meq} / \mathrm{L})\end{array} & \text { EC } & \mathrm{pH}\end{array}$


Arab Univ. J. Agric. Sci., Ain Shams Univ., Cairo, 13(3), 901-913, 2005

\begin{tabular}{|c|c|c|c|c|c|c|c|c|c|c|}
\hline $\mathrm{K}$ & $P$ & $\mathrm{~N}$ & $\mathrm{SO}_{4}$ & $\mathrm{Cl}$ & $\mathrm{HCO}_{3}$ & $\mathrm{CO}_{3}$ & $\mathrm{Na}$ & $\mathrm{Mg}$ & $\mathrm{Ca}$ & \\
\hline 3.5 & 0.4 & 111 & 5.8 & 1.5 & 3.7 & - & 5.4 & 1.1 & 4.0 & 1.1 \\
\hline \multicolumn{3}{|c|}{ Organic matter (\%) } & \multicolumn{8}{|c|}{ Available micronutrients (ppm.) } \\
\hline \multirow{2}{*}{\multicolumn{2}{|c|}{1.42}} & $\mathrm{CaCO}_{3}$ & \multicolumn{3}{|c|}{$\mathrm{Cu}$} & \multicolumn{2}{|c|}{$\mathrm{Zn}$} & \multicolumn{2}{|c|}{$\mathrm{Mn}$} & $\mathrm{Fe}$ \\
\hline & & 1.4 & & 15.7 & & \multicolumn{2}{|c|}{20.6} & \multicolumn{2}{|c|}{27.5} & 87.5 \\
\hline
\end{tabular}

1- Cultivation and Production of Medicinal and Aromatic Plants Department, National Research Center, Dokki, Cairo, Egypt.

2- Soils \& Water Use Department, National Research Center, Dokki, Cairo, Egypt.

(Received May 12, 2005)

(Accepted May 30, 2005) 
Arab Univ. J. Agric. Sci., Ain Shams Univ., Cairo, 13(3), 901-913, 2005

Table 3. Chemical analysis of used organic fertilizers

\begin{tabular}{|ccccccccccccc|}
\hline $\begin{array}{c}\mathrm{Ni} \\
\mathrm{ppm}\end{array}$ & $\begin{array}{c}\mathrm{Pb} \\
\mathrm{ppm}\end{array}$ & $\begin{array}{c}\mathrm{Cu} \\
\mathrm{ppm}\end{array}$ & $\begin{array}{c}\mathrm{Zn} \\
\mathrm{ppm}\end{array}$ & $\begin{array}{c}\mathrm{Mn} \\
\mathrm{ppm}\end{array}$ & $\begin{array}{c}\mathrm{Fe} \\
\mathrm{ppm}\end{array}$ & $\begin{array}{c}\mathrm{K} \\
\%\end{array}$ & $\begin{array}{c}\mathrm{P} \\
\%\end{array}$ & $\begin{array}{c}\mathrm{N} \\
\%\end{array}$ & $\begin{array}{c}\mathrm{EC} \\
(\mathrm{m} . \mathrm{mohs})\end{array}$ & $\mathrm{pH}$ & $\mathrm{O} . \mathrm{M} \%$ & Contents \\
\hline 16.45 & 32.29 & 10 & 84 & 245 & 2895 & 1.8 & 051 & 1.65 & 4.3 & 7.3 & 32 & $\begin{array}{c}\text { Sheep } \\
\text { Manure }\end{array}$ \\
50 & 60 & 35 & 200 & 320 & 2184 & 2.2 & 074 & 3.26 & 9.71 & 7.4 & 21.2 & $\begin{array}{c}\text { Chicken } \\
\text { Manure }\end{array}$ \\
\hline
\end{tabular}

\section{Vegetative growth parameters}

At fruiting stage, plant height $(\mathrm{cm})$, branch number/plant, leaf number/plant, umbel number/plant, fresh, dry weight (g/plant), and fruit yield (g/plant) were determined as average from replicates.

\section{Chemical analysis}

The followings chemical analysis were determined:

\section{Essential oil}

\section{A- Extraction of essential oil}

Dry herb (before flowering stage, during flowering stage and during fruiting stage) or ripening fruits $(50 \mathrm{~g})$ were subjected to Hydro distillation for $3 \mathrm{~h}$ using a Clevenger type apparatus (Clevenger 1928).

\section{B- Gas Chromatography-Mass Spectrophotometric (GC-MS) Analysis}

The components of essential oil extracted from dill (Anethum graveolens L.) fruits were determined according to (Adams 1995). Heavy metals content determination

\section{A- Heavy metals content determination in plant}

The samples (leaves at the flowering stage) were dried, ground and $\mathrm{Cu}, \mathrm{Zn}$, $\mathrm{Mn}, \mathrm{Fe}, \mathrm{Pb}$ and $\mathrm{Cd}$ extracted by acid digestion technique (Cottenie et al 1982), concentrations were determined by atomic absorption spectrophotometer Berken-Elmer (Gonzalez et al 1973).

\section{B- Heavy metals content determination in soil}

After dill harvesting at the two successive seasons, the heavy metals $\mathrm{Cu}$,

1- Cultivation and Production of Medicinal and Aromatic Plants Department, National Research Center, Dokki, Cairo, Egypt.

2- Soils \& Water Use Department, National Research Center, Dokki, Cairo, Egypt. 
Arab Univ. J. Agric. Sci., Ain Shams Univ., Cairo, 13(3), 901-913, 2005

$\mathrm{Zn}, \mathrm{Mn}, \mathrm{Fe}, \mathrm{Pb}$ and $\mathrm{Cd}$ extracted from soil by $\left(\mathrm{NH}_{4} \mathrm{HCO}_{3}\right.$-DTPA) extraction method (Soltanpour, 1985) and determined by atomic absorption spectrophotometer Berken-Elmer.

\section{Statistical analysis}

The means of the obtained data were statistically analyzed of the two successive seasons according to the procedure outlined by (Snedecor and Cochran 1990).

\section{RESULTS AND DISCUSSION}

\section{Effect of organic fertilizers (sheep manure and chicken manure) on the vegetative growth characters of dill (Anethum graveolens L.) plants}

Presented data in Table (4) showed the response of vegetative growth characters \{plant height $(\mathrm{cm})$, branch number/plant, leaf number / plant, umbel number/plant, fresh, dry weight (g / plant) and fruit yield ( $\mathrm{g} /$ plant $)\}$ in dill plant to the different rates of sheep and chicken manure. Data indicated that, all organic fertilizers treatments, i.e. mixture of sheep and chicken manure overcame the control treatment (except the treatment of $30 \mathrm{~m}^{3}$ sheep manure $+0 \mathrm{~m}^{3}$ chicken manure/ fed.) and improved the vegetative growth characters in both seasons. The highest values of vegetative growth characters were recorded with $10 \mathrm{~m}^{3}$ sheep manure $+20 \mathrm{~m}^{3}$ chicken manure / fed. which significantly overcame other treatments and lowest with $30 \mathrm{~m}^{3}$ sheep manure $+0 \mathrm{~m}^{3}$ chicken manure in both seasons. It could be concluded from the data that, increasing the ratio of chicken manure in fertilizer up to $20 \mathrm{~m}^{3} / \mathrm{fed}$. and decreasing sheep manure fertilizer up to $10 \mathrm{~m}^{3} / \mathrm{fed}$. improved the measurement of vegetative growth characters especially the fruit yield $(\mathrm{g} / \mathrm{plant})$ in both successive seasons.

Obtained results agreed with those of Borin et al (1987) and Brwaldh (1992), they reported that, organic manure is a rich and a slow release fertilizer which usage leads to a clean product of plants. They added that using organic fertilizer improves the soil texture. The structural improvement can encourage the plant to have a good root development by improving the aeration in the soil, which leads to a higher plant vegetative growth. Also the obtained results indicated the favorable effect of chicken manure on Anethum graveolens L. plant productivity, this results might be due to the role of organic manure for continues supply of nutrients, which improve some physical properties of soil and increase water retention than that for chemical fertilizers (Abd-Elmoez et al 1995 and Abd El-Fattah et al 1996).

Effect of organic fertilizers (sheep manure and chicken manure) on the essential oil percentage of dill (Anethum graveolens $\mathrm{L}$.) plants

Data in Table (5) indicated that, the highest percentage of essential oil obtained from the ripening fruits followed

1- Cultivation and Production of Medicinal and Aromatic Plants Department, National Research Center, Dokki, Cairo, Egypt.

2- Soils \& Water Use Department, National Research Center, Dokki, Cairo, Egypt. 


\section{Dill productivity}

by the herb during flowering stage, herb in the fruiting stage and the herb before flowering stage respectively in both seasons. Data showed the response of essential oil extracted from Anethum graveolens L. plant to the different rates of sheep and chicken fertilizers. Data indicated that all organic fertilizers treatments, i.e. mixture of sheep and chicken manure overcame the control treatment and improved the essential oil content in both seasons. The highest values of essential oil percentage were recorded with $10 \mathrm{~m}^{3}$ sheep manure $+20 \mathrm{~m}^{3}$ chicken manure / fed. which significantly overcame other treatments and lowest with control treatment in both seasons.

Obtained results agreed with those of Parakasa Rao et al 1997 who reported that. application of organic fertilizer increased total essential oil yields of davana plant and Marculescu et al 2002, they revealed that, the soil with its content in macro and microelements, enhanced by the use of organic fertilizers, plays an 
Arab Univ. J. Agric. Sci., Ain Shams Univ., Cairo, 13(3), 901-913, 2005

1- Cultivation and Production of Medicinal and Aromatic Plants Department, National Research Center, Dokki, Cairo, Egypt.

2- Soils \& Water Use Department, National Research Center, Dokki, Cairo, Egypt.

(Received May 12, 2005)

(Accepted May 30, 2005) 
9

Dill productivity

Table 5. Effect of organic fertilizers (sheep manure and chicken manure) on the herbal and fruit essential oil percentage of Dill (Anethum graveolenus L.) plants at two successive seasons of 2002/2003 and 2003/2004.

\begin{tabular}{|c|c|c|c|c|c|c|c|c|}
\hline \multirow{2}{*}{\multicolumn{2}{|c|}{$\begin{array}{l}\text { Fruit essential } \\
\text { oil percentage }\end{array}$}} & \multicolumn{6}{|c|}{ Herbal essential oil percentage } & \multirow[t]{3}{*}{ Treatments } \\
\hline & & \multicolumn{2}{|c|}{$\begin{array}{l}\text { During fruiting } \\
\text { stage }\end{array}$} & \multicolumn{2}{|c|}{$\begin{array}{l}\text { During flowering } \\
\text { stage }\end{array}$} & \multicolumn{2}{|c|}{$\begin{array}{l}\text { Before flowering } \\
\text { stage }\end{array}$} & \\
\hline $\begin{array}{c}2^{\text {nd }} \\
\text { Season }\end{array}$ & $\begin{array}{c}1^{\text {st }} \\
\text { Season }\end{array}$ & $\begin{array}{c}2^{\text {nd }} \\
\text { Season }\end{array}$ & $\begin{array}{c}1^{\text {st }} \\
\text { Season }\end{array}$ & $\begin{array}{c}2^{\text {nd }} \\
\text { Season }\end{array}$ & $\begin{array}{c}1^{\text {st }} \\
\text { Season }\end{array}$ & $\begin{array}{c}2^{\text {nd }} \\
\text { Season }\end{array}$ & $\begin{array}{c}1^{\text {st }} \\
\text { Season }\end{array}$ & \\
\hline 3.06 & 2.43 & 0.50 & 0.51 & 1.43 & 1.28 & 0.27 & 0.30 & $\begin{array}{l}\text { Recommended } \\
\text { NPK } \\
30 \mathrm{~m}^{3} \text { Sheep manure+ }\end{array}$ \\
\hline 3.25 & 2.79 & 0.53 & 0.53 & 1.48 & 1.54 & 0.29 & 0.31 & $\begin{array}{l}0 \mathrm{~m}^{3} \text { Chiken manure } \\
25 \mathrm{~m}^{3} \text { Sheep manure }+\end{array}$ \\
\hline 3.41 & 2.88 & 0.56 & 0.56 & 1.52 & 1.58 & 0.32 & 0.32 & $\begin{array}{l}5 \mathrm{~m}^{3} \text { Chiken manure } \\
20 \mathrm{~m}^{3} \text { Sheep manure+ }\end{array}$ \\
\hline 3.39 & 3.37 & 0.58 & 0.58 & 1.56 & 1.36 & 0.34 & 0.35 & $\begin{array}{l}10 \mathrm{~m}^{3} \text { Chiken manure } \\
15 \mathrm{~m}^{3} \text { Sheep manure+ }\end{array}$ \\
\hline 3.56 & 3.91 & 0.59 & 0.59 & 1.65 & 1.67 & 0.35 & 0.37 & $\begin{array}{l}15 \mathrm{~m}^{3} \text { Chiken manure } \\
10 \mathrm{~m}^{3} \text { Sheep manure }+\end{array}$ \\
\hline 4.13 & 4.10 & 0.63 & 0.64 & 1.71 & 1.75 & 0.39 & 0.38 & $\begin{array}{l}20 \mathrm{~m}^{3} \text { Chicken manure } \\
5 \mathrm{~m}^{3} \text { Sheep manure+ }\end{array}$ \\
\hline $3 . .21$ & 3.11 & 0.55 & 0.60 & 1.35 & 1.61 & 0.32 & 0.33 & $\begin{array}{l}25 \mathrm{~m}^{3} \text { Chiken manure } \\
0 \mathrm{~m}^{3} \text { Sheep manure }+\end{array}$ \\
\hline 2.90 & 2.92 & 0.55 & 0.59 & 1.33 & 1.60 & 0.30 & 0.33 & $30 \mathrm{~m}^{3} \mathrm{Chiken}$ manure \\
\hline 0.04 & 0.03 & 0.02 & 0.03 & 0.01 & 0.01 & 0.02 & 0.02 & L.S.D. at 0.05 \\
\hline
\end{tabular}

essential role in the plants development, in the biosynthesis of the organic substances at all level, also it can be noted that, when using manure, the amount of active principal (essential oil) is high in Chrysanthemum balsamita L. plant.

\section{Effect of organic fertilizers (sheep manure and chiken manure) on the chemical composition of essential oil extracted from dill (Anethum graveolens L.) fruits}

Results in Table (6) reveal that, the effect of organic fertilizers on the chemical composition of essential oil extracted from Anethum graveolens L. fruits. The main components was found to be (S)-Carvone (R) and Limonene, accounted for $53.07 \%$ and $33.7 \%$ respectively for control treatment. All organic fertilizer treatments increased the main components of essential oil extracted from Anethum graveolens L. fruits. Obtained results agreed with those of Jozef et al. 2002 and Marculescu et al 2002.

\section{Effect of organic fertilizers (sheep manure and chicken manure) on the heavy metals content of dill (Anethum graveolens $\mathrm{L}$.) plants}

Data presented in Table (7) showed the effect of used organic fertilizers on 
Arab Univ. J. Agric. Sci., Ain Shams Univ., Cairo, 13(3), 901-913, 2005

Table 6. Effect of organic fertilizers (sheep manure and chicken manure) on the chemical composition of essential oil extracted from Dill (Anethum graveolenus L.) fruits at two successive seasons of 2002/2003 and 2003/2004

\begin{tabular}{|c|c|c|c|c|c|c|c|c|c|}
\hline \multicolumn{8}{|c|}{ Treatments } & \multirow[t]{2}{*}{ RT } & \multirow[t]{2}{*}{ Components } \\
\hline $\begin{array}{c}0 \mathrm{~m}^{3} \\
\text { sheep } \\
\text { manure }+ \\
30 \mathrm{~m}^{3} \\
\text { chicken } \\
\text { manure }\end{array}$ & $\begin{array}{c}5 \mathrm{~m}^{3} \\
\text { sheep } \\
\text { manure }+ \\
25 \mathrm{~m}^{3} \\
\text { chicken } \\
\text { manure }\end{array}$ & $\begin{array}{l}10 \mathrm{~m}^{3} \\
\text { sheep } \\
\text { manure } \\
+20 \\
\text { chicken } \\
\text { manure }\end{array}$ & $\begin{array}{c}15 \mathrm{~m}^{3} \\
\text { sheep } \\
\text { manure + } \\
20 \\
\text { chicken } \\
\text { manure }\end{array}$ & $\begin{array}{c}20 \mathrm{~m}^{3} \\
\text { sheep } \\
\text { manure } \\
10 \mathrm{~m}^{3} \\
\text { chicken } \\
\text { manure }\end{array}$ & $\begin{array}{c}25 \mathrm{~m}^{3} \\
\text { sheep } \\
\text { manure }+ \\
5 \mathrm{~m}^{3} \\
\text { chicken } \\
\text { manure }\end{array}$ & $\begin{array}{l}30 \mathrm{~m}^{3} \\
\text { sheep } \\
\text { manure } \\
+0 \mathrm{~m}^{3} \\
\text { chicken } \\
\text { manure }\end{array}$ & $\begin{array}{l}\text { Recom } \\
\text { mended } \\
\text { NPK }\end{array}$ & & \\
\hline 0.08 & 0.6 & 0.20 & 0.09 & 0.09 & 0.70 & 0.97 & 1.01 & 6.69 & $\alpha$ Thujene \\
\hline 0.11 & 0.09 & 0.26 & 0.10 & 0.10 & 0.65 & 0.71 & 0.90 & 6.98 & $\alpha$-pinene \\
\hline 0.04 & 0.06 & 0.22 & 0.06 & 0.05 & 0.76 & 0.78 & 0.10 & 7.61 & Camphene \\
\hline 0.07 & 0.02 & 0.05 & 0.05 & 0.12 & 0.07 & 0.01 & 0.12 & 8.14 & Sabinene \\
\hline 0.12 & 0.10 & 0.04 & 0.11 & 0.11 & 0.09 & 0.03 & 0.14 & 8.33 & $\beta$-Pinene \\
\hline 0.20 & 0.80 & 0.21 & 0.21 & 0.99 & 0.54 & 0.77 & 0.97 & 8.99 & $\alpha$-Phellandrene \\
\hline 0.67 & 0.47 & 0.50 & 0.52 & 0.37 & 1.47 & 1.43 & 1.57 & 9.15 & $\alpha$-Terpinene \\
\hline 36.80 & 37.07 & 37.20 & 36.95 & 36.67 & 35.25 & 34.90 & 33.70 & 9.40 & (R)-Limonene \\
\hline 0.05 & 0.07 & 0.10 & 0.09 & 0.05 & 0.11 & 0.14 & 0.22 & 9.73 & $\beta$-Phellandrene \\
\hline 0.49 & 0.29 & 0.40 & 0.44 & 0.31 & 1.27 & 1.34 & 1.56 & 10.13 & p-Cymene \\
\hline 0.30 & 0.10 & 0.05 & 0.25 & 0.08 & 0.26 & 0.29 & 0.37 & 10.41 & 1,8- Cyniol \\
\hline \multirow[t]{2}{*}{0.04} & 0.09 & 0.20 & 0.08 & 0.07 & 0.20 & 0.18 & 0.29 & 11.95 & p-Cymenene \\
\hline & & & & & & & & & Cis-2-Menthen- \\
\hline 0.08 & 0.10 & 0.09 & 0.09 & 0.07 & 0.12 & 0.10 & 0.14 & 12.17 & $1-01$ \\
\hline \multirow[t]{2}{*}{0.32} & 0.21 & 1.49 & 0.34 & 0.20 & 1.31 & 1.29 & 1.37 & 15.37 & Dill ether \\
\hline & & & & & & & & & Cis- \\
\hline 0.11 & 0.09 & 0.01 & 0.10 & 0.06 & 0.11 & 0.12 & 0.16 & 15.82 & $\begin{array}{l}\text { Dihydrocarvone } \\
\text { Trans- }\end{array}$ \\
\hline 1.25 & 1.17 & 0.11 & 1.24 & 1.49 & 1.97 & 1.02 & 4.15 & 16.44 & Dihydrocarvone \\
\hline 59.00 & 59.10 & 59.00 & 58.80 & 58.73 & 54.90 & 55.66 & 53.07 & 18.10 & (S)- Carvone \\
\hline 0.05 & 0.03 & 0.01 & 0.08 & 0.11 & 0.06 & 0.07 & 0.06 & 19.34 & Carvacrol \\
\hline 0.03 & 0.01 & 0.02 & 0.09 & 0.09 & 0.07 & 0.09 & 0.05 & 21.87 & Germacrene \\
\hline
\end{tabular}

1- Cultivation and Production of Medicinal and Aromatic Plants Department, National Research Center, Dokki, Cairo, Egypt.

2- Soils \& Water Use Department, National Research Center, Dokki, Cairo, Egypt.

(Received May 12, 2005)

(Accepted May 30, 2005) 
Dill productivity

Arab Univ. J. Agric. Sci., 13(3), 2005 
Arab Univ. J. Agric. Sci., Ain Shams Univ., Cairo, 13(3), 901-913, 2005

1- Cultivation and Production of Medicinal and Aromatic Plants Department, National Research Center, Dokki, Cairo, Egypt.

2- Soils \& Water Use Department, National Research Center, Dokki, Cairo, Egypt.

(Received May 12, 2005)

(Accepted May 30, 2005) 
Dill productivity

Arab Univ. J. Agric. Sci., 13(3), 2005 
the heavy metals content of Anethum graveolens L., all treatments of organic fertilizers decreased the heavy metals content especially the treatments of $10 \mathrm{~m}^{3}$ sheep manure $+20 \mathrm{~m}^{3}$ chicken manure.

These results agreed with those of Marculescu et al (2002), they said that, metallic pollutant (heavy metals) are not degraded during composting but may be converted into organic combinations that have less bio availability than mineral combinations of the metals.

\section{Effect of organic fertilizers (sheep manure and chicken manure) on the heavy metals in soil}

Data in Table (8) show the available concentration of heavy metals in the soils after dill harvesting at the two successive seasons as affected by the addition of organic matter. It is noticed that, there is a difference between the two growth seasons for concentration of each element and also from one element to another .For example, the behavior of $\mathrm{Zn}$ and $\mathrm{Cu}$ differed from those of $\mathrm{Pb}$ and $\mathrm{Cd}$, which took an opposite trend.

Data of available elements show that there are significantly increase in the DTPA-extractable of $\mathrm{Fe}, \mathrm{Mn}, \mathrm{Zn}$ and $\mathrm{Cu}$ in soil as affected by addition of chicken and sheep manure compared with the control treatment. On the other hand, addition of chicken and sheep manure to the soil significantly decreased the extractable $\mathrm{Pb}$ and $\mathrm{Cd}$ compared with the control treatment.

Data also, show that, the application of chicken manure to the soil significantly increased the studied heavy metals when compared with those obtained by using sheep manure, the relative values of DTPA - extractable heavy metals at the end of the experiment can be arranged in the decreasing order as follow: $\mathrm{Fe}>\mathrm{Mn}>\mathrm{Cu}>\mathrm{Zn}>\mathrm{Pb}>\mathrm{Cd}$ respectively.

The obtained results of the DTPA-extractable heavy metals in the soil at the end of the experiment lay in the common range as stated by Ewers (1991). Also these results indicated that the application of organic manure increased the availability of plant nutrients and reduced the harmful effects of hazardous heavy metals.

\section{REFERENCES}

\author{
Abd-Allah, A.M.; S.M. Adam and A.F. \\ Abou-Hadid (2001). Productivity of \\ green cowpea in sandy soil as influenced \\ by different organic manure rates and \\ sources. Egypt. J. Hort. Sci., 28 (3): \\ 331- 340.
}

Abd El-Fattah, A.; M.R. Abd-Elmoez and M.H. Ghali (1996). Impact of various organic wastes on physicochemical properties of sandy soil and nutrients content in broad bean. Egypt $\boldsymbol{J}$. Appl. Sci.,11(124): 96-111.

Abd-Elmoez, M.R.; M.H. Ghali and A. Abd El-Fattah (1995). Conditioning of a sand soil by organic wastes and its impact on N-concentration and yield of broad bean. Zagazig J. Agric. Res., 22(11): 221-233.

Adams, R.P. (1995). Identification Of Essential Oil Components By Gas Chromatography/Mass Spectroscopy. pp. 1-29. Allured, Carol, Stream, Illinois, U.S.A.

Barker, A.V. and G.M. Bryson (2002). Bioremediation of heavy metals and organic toxicant by compositing. The Scientific World J., 11 (2): 407-420. 


\section{Dill productivity}

Borin, M.; C. Giupponi and F. Osele (1987). The effect of organic and mineral fertilizer and soil type on potato tuber formation. Information Agrario, 43 (9): 116-122.

Brwaldh, M. (1992). Influence of organic and inorganic fertilizer on common bean (Phaseolus vulgaris L.) grown in P-fixing malic andosol. Biol. Agric. and Hort., 9 (8): 45-56.

Clevenger, J.F. (1928). Apparatus for determination of essential oil. $\mathbf{J} . \mathbf{A m r}$.

Pharm. Assoc., 17: 346-349.

Cottenie, A.; M. Verloo; L. Kiekens, G. Velghe and R. Camerlynck (1982). Chemical Analysis of Plant and Soil. pp. 100-129. Laboratory of Analytical and Agrochemistry, State Univ., Ghent, Belgium.

Delaquis, P.J.; K. Stanick; B. Girard and G. Mazza (2002). Antimicrobial activity of individual and mixed fractions of dill, cilantro, coriander and eucalyptus essential oils. Int. J. Food Microb., 74: 101-109.

Duke, J.A. (2001). Handbook of Medicinal Herb. p. 42. CRC Press, London.

Ewers, U. (1991). Standards, Guidelines and Legislative Regulations Concerning Metals and Their Compounds. pp. 687771. E VCH Publ., New York. Fleming, T. (2000). PDR for Herbal Medicines. pp. 252-253. Medical Economic Company, New Jersy, USA. Gonzalez, C.; M. Banez; M. Wylle and J. Sole (1973). La Nutricion Miniral de le Vegetables. p. 134, Facultad de Agronomia, Universidad Catulica de Chile.

Hornok, L. (1980). Effect of nutrition supply on yield of dill (Anithum graveolens L.) and the essential oil content. Acta Hort., 96: 337-342.
Hosseinzadeh, H.; G.R. Karimi and M. Amen (2003). Effect of Anithum graveolens $\mathrm{L}$. seed extracts on experimental gastric irritation models in mice. BMC Pharmacol., 2 (1): 21-29. Huopalahti, R. and R.R. Linko (1983). Composition and content of aroma compounds in dill (Anithum graveolens L.) at three growth stages. J. Agric. Food Chem., 31: 331-333.

Hussien, M.S. (1995). Response of growth, yield and essential oil of coriander and dill to different nitrogen sources. Egypt. J. Hort. Sci., 22 (1): 110. Jackson, M.L. (1973). Soil Chemical Analysis. pp. 200-250. Published by Prentice-Hall of Indian Private Limited. New Delhi-1.

Jozef, G.; A. Lis; J. Kula; M.

Staiszewska and A. Woloszyo (2002). Chemical composition variability of essential oil in the ontogenesis of some plants. Flavour and Fragr. J., 17: 445451.

Khalid, Kh. A. (1996). Effect of Fertilization on The Growth, Yield and Chemical Composition of Some Medicinal Umbelleferous Plant. pp. 1-5. M.Sc. Thesis, Fac. Agric., Al-Azhar Univ. Cairo. Egypt.

Marculescu, A.; C. Sand; C.H. Barbu; D. Babit and D. Hanganu (2002). Possibilities of influencing the biosynthesis and accumulation of the active principals in Chrysanthemum balsamita L. Specie Roum. Biotechnol. Lett.; 7 (1): 577- 548.

Oasterhaven, K.; B. Poolman and E.J. Smid (1995). S- carvon as natural potato sprout inhibiting, fungistatic and bactristatic compound. Ind. Crop. Prod., 4:23-31. 
Parakasa Rao, E.V.S.; M.R. Naryana and B.R. Rajeswara (1997). The effect of nitrogen and farm yard manure on yield and nutrient uptake in davana (Artemisia pallens Wall. ExD.C.). J. Herbs, Spices and Medicinal Plants. 5 (2):39-48.

Snedecor, G.W. and W.G. Cochran (1990). Statistical Methods. $11^{\text {th }}$ Ed. pp. 369-375. Iowa State Univ, Press. Ames, Iowa, U.S.A.

Snyman, H.G.; D.E. Jong and T.A.S. Aveling (1998). The stabilization of sewage sludge applied to agricultural land and the effects on maize seedlings.

Water Sci. Technol., 38 (2): 87-95.

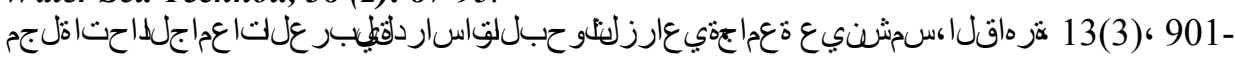
913، 2005

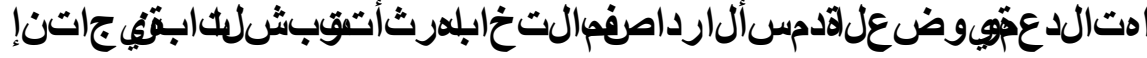

]60[

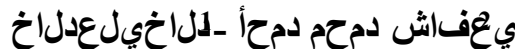

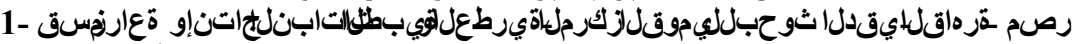

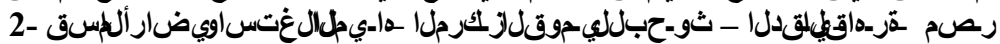

$$
\text { نيمسوملالتغبشلكثابن ةعارزمت }
$$

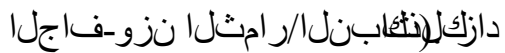

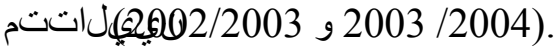

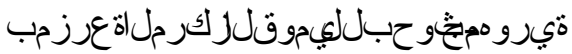

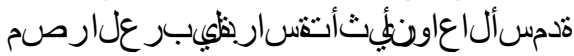

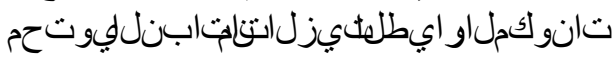

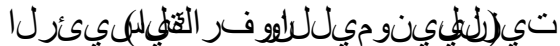
توبشلشثابنر امث منعلخت خسملعا ايطل

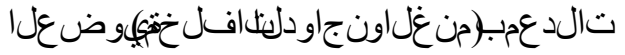

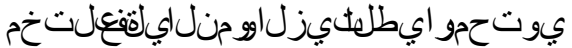

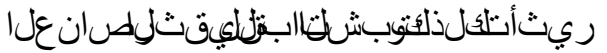

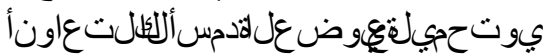

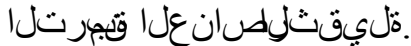

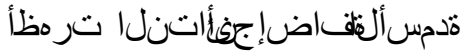

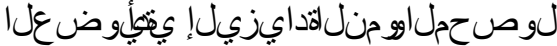

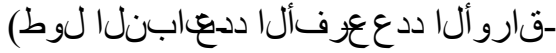

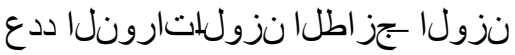

Soltanpour, P.N. (1985). Use of ammonium bicarbonate- TPA soil test to toxicity. Commun. Soil Sci. Plant Anal., 16: 323-338.

Yazdanporast, R. and M. Alavi (2001). antihypercholeserolaemic effects of Anithum graveolens L. leaves after the removal of four cumarins. Cytobios., 105: 185-191.

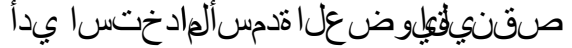

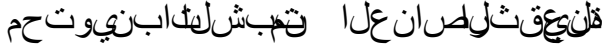

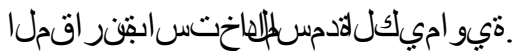

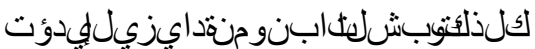

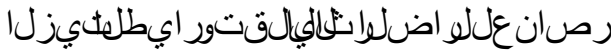

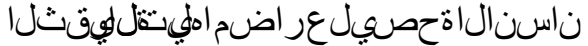

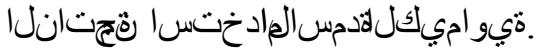

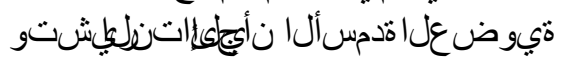


Arab Univ. J. Agric. Sci., Ain Shams Univ., Cairo, 13(3), 901-913, 2005

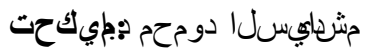<smiles>[Mg][Mg][Mg][Mg]</smiles>

1- Cultivation and Production of Medicinal and Aromatic Plants Department, National Research Center, Dokki, Cairo, Egypt.

2- Soils \& Water Use Department, National Research Center, Dokki, Cairo, Egypt.

(Received May 12, 2005)

(Accepted May 30, 2005) 